\title{
China-Pak Strategic Entente With Respect To Search For Reciprocated Security Through Gwadar Port
}

\author{
Fakhar Hussain ${ }^{1}$, Sarfraz Hussain ${ }^{2}$, Nisar Ahmad ${ }^{3}$, Abdul Quddus ${ }^{4}$, Muhammad \\ Rafiq5, Tien Phat Pham ${ }^{6}$ \\ ${ }^{1}$ Lecturer in Civics at Government Imamia Degree College Sahiwal, Pakistan. \\ ${ }^{2}$ Azman Hashim International Business School, Universiti Teknologi Malaysia, Kuala Lumpur, Malaysia \\ Assistant Professor: Govt. Imamia College Sahiwal, Pakistan \\ ORCID: 0000-0001-9449-1047 \\ ${ }^{3}$ Assistant Professor Hailey College of Commerce, University of the Punjab Lahore, Pakistan. \\ ${ }^{4}$ Faculty of Management and Economics, Tomas Bata University in Zlin, The Czech Republic \\ ORCID: 0000-0003-3914-6755 \\ ${ }^{5}$ Azman Hashim International Business School, Universiti Teknologi Malaysia, Kuala Lumpur, Malaysia Prince \\ Mohammad Bin Fahd University, Akhobar, Dammam, Saudi Arabia \\ ${ }^{6}$ Faculty of Management and Economics, Tomas Bata University in Zlin, The Czech Republic School of \\ Economics, Can Tho University, Vietnam \\ ORCID: 0000-0001-9472-5878 \\ Email: ${ }^{1}$ diplomat786@gmail.com, ${ }^{2}$ mianfraz1@gmail.com, ${ }^{3}$ nisar@hcc.edu.pk, ${ }^{4}$ quddus@ utb.cz, \\ ${ }^{5}$ rafiq.m@graduate.utm.my, ${ }^{6}$ phamphattien@gmail.com
}

\begin{abstract}
The strategic bond between China and Pakistan has remained to be on an ascending trajectory, thought to be ascertained as an excessive significance for the promotion of their long-lasting objectives of geo-strategic interests. China has been providing Pakistan economic, military and political support desired for balancing the relationship vis-à-vis India and the US. The strategic knot between China and Pakistan is for that reason essential for the empowerment of China to minimize Indian desires for emerging as a regional hegemon, and for counter-balancing Indo-US strategic correlation. This research aims the strategic relationship of two neighboring countries of Pakistan and China concerning emphasizing their search for reciprocated security through Gwadar port to be viewed as a win-win situation for China and Pakistan.
\end{abstract}

Keywords: Sea Lines of Communications (SLOCs), Second Strike Capability, Energy Supplies, Sensitive Defense Zone (SDZ), Strategic Depth, People's Liberation Army \& Navy (PLAN).

\section{Introduction}

The China-Pakistan strategic relationship has strengthened with time under the changing dynamics of regional politics. The strategic bond between China and Pakistan has remained to be on an ascending trajectory, thought to be ascertained as an excessive significance for the promotion of their long-lasting objectives of geo-strategic interests, and has gradually developed into equally advantageous strategic partnership incorporating huge areas of collaboration (Javaid and Javaid, 2016). China has been providing Pakistan with the economic, political, and military support it has looked-for balancing relations with the US and India (Kabraji, 2012). China considers Pakistan as a significant neighbor endowed

by geostrategic position and having landroute admittance to the Persian Gulf and inhabiting an imperative position in the Islamic world. With the growth of China in military and economic perspectives, it desires for ensuring peace and harmony within its territorial limits. China has been conscious regarding the vulnerability of marine ships through sea routes mainly the Strait of Malacca termed as the "Malaccan Dilemma" (Darshana, 2018).

China has serious concerns concerning the likelihood of interruptions 
in the smooth transportation of oil and gas shipment tankers towards China from Africa and the Gulf region through the Strait of Malacca about attacks by the pirates or terrorists. Based on it, China desires for reduction of its dependency on the Strait of Malacca and has been making efforts for the development of alternative transit routes (Hussain, 2020). Chinese $80 \%$ of energy imports have been flowing through Malaccan Strait which is thought to be an insecure trading route and also to be notorious for piracy. China is wary that case the US would cut-off its energy supplies coming throughout the Strait of Malacca instead of antagonisms on the issue of Taiwan (Hasan, 2012).

China has been looking for alternate routes for safeguarding energy supplies. Gwadar has been a significant place of geo-strategic value, providing enormous promotion to Pakistan's prominence in the entire area. Gwadar may enable China to the diversification of the routes of oil imports. China-Pak close relations will create geostrategic and geopolitical balance in the region. Gwadar will turn out to be a vital route for China under the emerging geostrategic milieu (Kakar, 2014). Washington perceives Gwadar as part of the "String of Pearls Strategy" by China that seeks projection of its power overseas even though safeguarding the energy supplies and has also been concerned with the strategic influence that China will gain by setting up of electronic surveillance listening post at Gwadar for monitoring of shipment traffic (Pascu, 2011).

Pakistan's geostrategic significant position and resourcefulness has made it a blistering destination for global entrepreneurs and due to which China is going to become the largest investment partner in Pakistan. Chinese evolving influence in the area is expedient for its wide-ranging global strategy that has been planned to expand, secure and increase the much-needed supplies of energy (Kalim, 2016). The position of Gwadar Port near Central Asia, South Asia and the Middle Eastern States has transformed it to be a western-most interlink under the Chinese "String of Pearls" strategy on accounts of which it has considered getting hold to key-strategic seaports under its One Belt, One Road (OBOR) initiative. OBOR project is thought to be strategic, which has not only been aimed at domestic and regional economic development but is primarily focused to increase its notion of power beyond its near abroad (Javaid and Javaid, 2016).

The deepwater seaport at Gwadar has been envisaged as being a center of the region, serving the commercial traffic to and fro from the Central Asian Republics (CARs), Afghanistan, the Middle East, Persian Gulf, South East Asia, Iran, and Xinjiang. Gwadar may help China for outspreading its existence in the regions of the Arabian Sea and the Persian Gulf countries from where it is importing about $60 \%$ of supplies of its energy needs. Utilization of Gwadar for being a prevailing inland interlink would be helpful for China in cultivating its constantly growing trade with Middle Eastern; Central Asian and African countries by reducing the sea distance of 10,000 to $2500 \mathrm{Km}$ (Azhar, 2015). The China-Pakistan relationship is unique and valuable from various accounts. This collaboration ranges from technology, industry to political, economic, social, cultural, educational, diplomatic, and military. The milestone agreement of the China-Pak Economic Corridor is one of the turning points between the two nations. This trading corridor would open up new vistas of opportunities for the people of Pakistan in the long run and also benefit China. Gwadar is significant for Pakistan to make sure its security and naval interests in the region based on increasing geo-economic and geopolitical influence in the 
chessboard of regional setup (Fazl-eHaider, 2009).

Pak-Indian antagonism due to unresolved disputes has given "lifeblood" to Pak-China entente cordiale. In the context of larger geographic perception, geo-strategic apprehensions of contending regional powers like India, China, and Pakistan with their coinciding assertions have produced multifarious domains of collaborations (Kabraji, 2012). As contemporary geopolitical dynamics disclose with the US "pivot to Asia", the enmity and competition between the US and China are escalating, bringing with it analogous dynamics in South Asia as Pakistan moves closer to China and India combines its alliance with the US. Pakistan and China have remained strategic partners in the changing geostrategic environment (Small, 2015). China and Pakistan have been able to make an effective delusion, with the inadvertent support of hardline elements in Washington and New Delhi, that China has to be a real replacement for the US and in that way a threat to both India and the US interests in the region (Kabraji, 2012).

The China-Pakistan relationship is one of the long-standing relationships in the region, one that continues to grow stronger in an era that is witnessing significant changes at the regional and international levels. Subsequently, since the termination of the Cold War era, the relationship between Pakistan and China has progressively been developed into multi-dimensions. In the shifting international setup since $9 / 11$, observed extreme development in China-Pak militaristic and strategic relationship (Schwemlein, 2019). In the changing geostrategic environment, both nations comprehend the need for nuclear and missile assistance to face challenges of evolving local and international security environment, predominantly after the conclusion of the US-Indian Civilian-
Nuclear Agreement (Small, 2015). China has been providing Pakistan economic, military, and political support desired for balancing relationship vis-à-vis India and the US, about the geo-strategic priorities of Beijing (Kalim, 2016). While Pakistan and China have mutual interests in the regional security environment, the central interlink has been based on reciprocated give-andtake and non-interference policy in internal matters, avoiding a clash of core vital national interests. The strategic bond between China and Pakistan is for that reason essential for the empowerment of China to minimize Indian desires for emerging as a regional hegemon, and for counter-balancing Indo-US strategic correlation (Jetly, 2012).

The core intentions behind the adjacent partnership and strategic coalition amidst China and Pakistan remained for the counterbalance of the growing Indian effect. Despite the dissimilarities in culture, history, religion, language, race, economic and political systems, and ideological moorings, their friendship has continuously been on an ascending curve. It has been likely because their association is based on deep mutual respect and trust, understanding and common aspirations for maintenance of peace and progress (Javaid and Javaid, 2016). The china-Pak strategic coalition has been defined by officials as being an equally advantageous relationship built on respect and "multi-dimensional" collaboration (Kabraji, 2012). China and Pakistan jointly will outline the security architecture of Asia and may determine regional economic and strategic terrain for many years to come (Darshana, 2018).

\section{Importance of China-Pak Strategic Collaboration for China}

The china-Pak relationship is considered as time-tested, deep-rooted, and evergrowing. This bilateral association has been established in a wide-ranging manner and progressively it has been improved to 
a strategic partnership. China-Pak mutual collaboration in the fields of economy, politics, militaristic spheres specifies the strength and depth of China-Pak geostrategic-partnerships (Javaid and Javaid, 2016). South Asia is in the midst of a geopolitical transformation. China, Central, and South Asian countries will play a leading role in both the economic integration and the future security architecture of the region. The rise of China introduces not only a player in the dynamics of South Asian, but also highlights the underlying fact of Beijing's influence in the region. Chinese engagements in South Asia are an upshot of its global ambitions to be a great power (Darshana, 2018). China has a definite interest in Pakistan's security and territorial integrity. This mutuality of interests acquires critical salience in the fast-evolving global power alignments and adjustments. China-Pak strategic relations are probable for strengthening and becoming active amid geo-economic dimensions to intensify their mutual strategic alliance (Small, 2015).

China will continue to maintain a robust defense relationship with Pakistan and to view a strong partnership with Pakistan as a useful way to contain Indian power. The strategic angle to the PakistanChina relationship will, however, remain, and China will continue to use Pakistan to cap India's geo-strategic ambitions. Their relationship has matured from a tactical alliance to a strategic partnership in the context of burgeoning Indo-US relations in the politico-strategic, military, and nuclear fields (Javaid and Javaid, 2016). China's continuing expansion of relations with Pakistan has positioned Beijing for maximization of its influence, seizure of market space, and advancement of the military to military bonds in the coming years (Schwemlein, 2019). Chinese support to Pakistan from its long-term strategic perceptions may predominantly be in three wide-ranging areas: Geo- strategic significance of Pakistan in safeguarding admittance to the vast emerging natural resources in West Asia and Central Asia; its value in the containment of Indian power and influence; and its effectiveness to China in its long term bid for countering the US global hegemony in the context of shifting strategic alignments in South Asia and South-west Asia (Jetly, 2012).

The growing centrality of South Asian rivals in the US and Chinese strategic equation is expected to prominently surface in geostrategic and geo-economic trajectories (Javaid and Javaid, 2016). It has become the highest priority of world powers in the Arabian Sea for ensuring a continuous flow of transit trade and the autonomy of navigation. Beijing has likely been to maintain largely an economic viewpoint about (IOR) rather than militaristic to come across its growing demands of energy supplies, being contingent to the nautical deliveries from foreign nations. With the presence of great powers in the region, there will be incentives for China to maintain permanence at sea for the protection of economic concerns (Neo, 2013). Gwadar port being transformed into a military base of China, it would provide the Navy of China with a permanent platform in the Indian Ocean (Gill, 2019). The strategic, economic, and military potential of Gwadar Port would bring Pakistan and China in dynamic maritime collaboration about the shipment, navigational autonomy, execution of the international laws of sea and coastline defense (Kalim, 2016). Gwadar Port has been dubbed as a crowning jewel in the "String of Pearls" for China to its geographical advantages of being $400 \mathrm{Km}$ away from the Strait of Hormuz suggesting for "strategic \& militaristic" significance concerning the proposal by China in 2009 to the US Pacific Fleet Commander suggesting that Indian Ocean would be accepted as being Chinese 
sphere of influence (Neo, 2013) assuming that the US will decrease military ships manipulating influence in the region with the involvement of allies possessing growing naval powers (Pascu, 2011).

Bearing in mind the military developments and maritime capabilities of Japan, India, and China, the US may be presumed to adopt a policy analogous to the British Empire for the period of the late $19^{\text {th }}$ Century. Consideration of Gwadar Port in control of the US, it would serve to be an effective platform for the furtherance of the US objectives of maintenance of hegemony, controlling hydrocarbon and mineral reservoirs of the Gulf; Central Asian countries and the states of South Asia as well as for Russian and Chinese containment (Pascu, 2011). China-Pak close relations will create geostrategic and geopolitical balance in the region. Gwadar will turn out to be a vital route for China under the emerging geostrategic milieu (Hussain and Hussain, 2017).

The Indo-US apprehensions have been growing about the involvement of China in Pakistan and have been considered to be a potential threat. It is projected that the US would be relying on Indian and Japanese naval support to counterweight the influence of China in the designated maritime regions. India has been establishing naval bases and strategic listening posts at Madagascar, Mauritius, and Seychelles Islands concerning its consideration of the Pak-China alliance as a tangible threat being materialized due to the construction of Gwadar Port as a bid to allow for control of the Strait of Hormuz (Pascu, 2011). Gwadar may serve to be an auxiliary trading route for China in this manner, permitting China to outmaneuver the threat of naval blockade of energy supplies of China through Malacca Strait by allied navies and the US in the future perspective of a war in Asia (Yan, 2012). In strategic \& military expressions, Gwadar will be supportive of China for monitoring (SLOCs) initiating from the Gulf and being a source of about $60 \%$ of the energy requirements of China. It will also make available to China a strategic listening post (Hasan, 2012) and Beijing would also desire to exercise substantial influence by monitoring the USA fleet activities in the Gulf region, nautical endeavors of India in the IOR and IndoUSA future seagoing collaboration (Naseem, 2014).

China is conscious about the significance of its mercantile development and militaristic capabilities based on which it would be able to counterbalance the optimizing influence of India. China has apprehensions regarding the growing influence of India in the IOR, predominantly ever since the Indo-US "civilian-nuclear" deal that has been worrisome for Pakistan and China regarding long term strategic and economic regional interests. Gwadar has gained extreme consideration from the very beginning based on its strategic position and the establishment of strong militaristic ties between China and Pakistan. The security of Sea Lines of Communications (SLOCs) is of enormous significance for countries having seaborne transit trade (Kalim, 2016). Gwadar has geostrategic prominence by positioning horizontal across SLOCs stemming through the strategic chokepoint of Hormuz Strait (Hasan, 2012).

India has viewed China as a potential threat and has been surrounded by three sides of Tibet, Myanmar, and Pakistan by Chinese influence. Iran would also be viewing China as a threat due to Gwadar being thought of depriving Iran of its economic profits. India perceives the "Port of Gwadar" as a strategic naval-base of China, which would likely be developed as a strategic homeport naval base equipped with nuclear submarines and aircraft carriers. Self-determining scholars consider that the existence of China at 
Gwadar will discourage Indian strategy for dominating the regional waterways. The Indian navy has been struggling with the transformation from being a littoral naval force to the largest blue waters naval force of the region. It has been consolidating military positions in Andaman and the Nicobar archipelagos for the exertion of control to the Strait of Malacca (Pascu, 2011). India's topmost priority is the accomplishment of dominant power status in the IOR in collaboration with Australia \& the USA (Kalim, 2016). China questions the prevailing order and intends to create a structure advantageous to its interests. India presently lacks the resources to contest China in terms of global power ambitions, and this shift unquestionably affects the strategic and national interests of New Delhi. Other states like Australia, France, Germany, the $\mathrm{UK}$, and the United States are keen to see India playing a leading role in the region (Darshana, 2018).

China has been getting hold of the strategic-seaports of the region under its "String of Pearls Strategy". The location of these seaports depicts a figure of string (of pearls) on the world map which has been considered as China's lines of defense for controlling the transportation of $80 \%$ of its oil and energy resources utilized in China has been transported over these carriage lanes of the Strait of Malacca (Naseem, 2014). In comparisons with the "String of Pearls" philosophy, the Chinese narrative inclines to portrait the strategy of the Indian Ocean in wide-ranging economic and marine security perspectives. India and the US have been holding dominance over the significant shipment traffic lanes for an extensive period by posing a Malacca Strait dilemma for China (Jetly, 2012). The naval activities of India in areas of the Gulf and the area of "Gulf of Aden" have always persisted an eye-sour for the Chinese. China has been in the need of a balancer to counterbalance India for dilution of the effects of its hegemonic emergence. Pakistan is the country that can act as a balancer for China in the region. In this perspective, China has been well aware of the significance of Pakistan card (Hasan, 2012).

The emergence of Pak-China strategic and naval collaboration has become inevitable for counteracting the militaristic Indo-Israel nexus. The establishment of a naval strategic base at the opening of the Indian Ocean would be helpful to China for observing the hegemonic designs of India in the region. In case of a crisis with India, Gwadar Port will provide Pakistan with strategic depth to Naval and the commercial resources (Azhar, 2015). It is situated near the Indian Ocean highways which have been a corridor of about $80 \%$ of global trade of oil and raw materials transported to Europe, America, and the Far East. Therefore Gwadar is strategically positioned at a strategic point to create disruptions in the smooth flow of commercial trading, as India and the US look at Chinese investment in the construction of Gwadar Port with similar perceptions, since the time China has been consolidating footholds in the Indian Ocean with the establishment of seaports originating from China Sea to the Persian Gulf (Shahnaz, 2015).

The USA perceives China as being a key regional competitor and has been concerned about the swift growth of Chinese might and influence in Asia. Pentagon is worried regarding Chinese monitoring of the USA-naval activity in the Gulf conceivably through the Gwadar Port which would also fuel the suspicions towards Pak-China relations being felt by the US for long. Washington has been viewing Gwadar as being "Chinese Gibraltar" (Kalim, 2016). The naval presence of China at the significant energy chokepoint of the Gulf would also for checking the US-Indian dominance of the IOR. Some of the scholars have argued 
that Gwadar would become a naval base of China in the Indian Ocean enabling Beijing for monitoring Indo-US nautical activities based on which it can also be called the western-most link China under its "String of Pearls" strategy (Jetly, 2012).

Gwadar would be capable of providing a strategic listening outpost to China for observing the US naval activities in the Persian Gulf some $460 \mathrm{Km}$ from Karachi, being further away from Gujrat and Mumbai Naval bases of India (Hasan, 2012). Consideration of the US for having admittance of China to Gwadar will make it capable of getting rid of the lengthy and susceptible SLOCs that may be helping for economic and marine potential. In terms of military and strategic perspectives, Gwadar would help China for monitoring (SLOCs) emanating from the Persian Gulf. It is estimated that $60 \%$ of the required energy supplies of China have been coming from the Gulf and transported from end to end this key transit traderoute. The naval presence of China may likely strengthen the coastline defense of Pakistan (Neo, 2013).

Gwadar will make the availability of a frontward base to China for monitoring of the US-naval patrols in the Gulf and New Delhi's nautical designs across the Arabian-Sea. Analogous situations would also prevail in the area of the Bay of Bengal and the Coca Island in Myanmar where China has established the facilities to monitor the maritime activities of India and the test firing of missiles in Orissa (Naseem, 2014). With the stationing of Chinese marines at such a vital position, China would be in the position of monitoring activities by the US naval forces as well as it will also have the capability of striving for achieving the status of being a world naval power (Yeuh-Yun, 1972). Pakistan has made known of its intentions regarding development of Gwadar with the capabilities of militaristic projections to be built as a naval base with the help of China. Pak-China strategic alliance has created trust for the facilitation of interoperability between them predominantly vis-à-vis India (Neo, 2013).

Gwadar Port will facilitate China with strategic footholds in the Arabian-Sea as well as the region of IOR. It would prove to be a daunting prophecy as being full-fledged and an offshore naval base of (PLAN) of China. It has been considered as third largest seaport in the world which would be able to accommodate the submarines and defender naval ships of China for ensuring safety of the Arabian Sea and security of its smooth supply lines of energy, as well as it would also help Pakistan for strengthening naval forces of Pakistan against outmatched expansion of Indian Navy (Kalim, 2016). According to experts, Washington perceives Gwadar as part of the "String of Pearls Strategy" by China that seeks projection of its power overseas even though safeguarding the energy supplies and has also been concerned with the strategic influence that China will gain by setting up of electronic surveillance listening post at Gwadar for monitoring of shipment traffic (Azhar, 2015).

It will help China for counterbalance of the US policy of "Pivot to Asia" designed for containment and encirclement of China with the establishment of alliance comprising India, Australia, Japan, Vietnam, Singapore, Philippine and South Korea. In the military and strategic terms, Gwadar would be helpful for monitoring (SLOCs) the Strategic Lines of Communications, which has been originating through Persian Gulf and bottle-neck at Hormuz strait, as Chinese chief requirements of energy is coming from Persian Gulf countries, which transits along this significant sea lane (Jetly, 2012). Beijing can aspire to exercise considerable influence in the region, and also monitor the US naval 
activity in the Persian Gulf, Indian naval activities in the Arabian Sea, and the future Indo-US maritime collaboration in the Indian Ocean (Kabraji, 2012).

\section{Importance of China-Pak Strategic Collaboration for Pakistan}

Pakistan and China have been sharing a friendship which is thought to be ascertained as an excessive significance for the promotion of their long-lasting objectives of geo-strategic interests, and has gradually developed into equally advantageous strategic partnership incorporating huge areas of collaboration (Javaid and Javaid, 2016). The alliance is imperative to Pakistan's existence faced with the looming and imminent threat of a much larger, more powerful neighbor. Pakistan enjoys China's Big Brother status, given the fluctuating love-hate relationship that Islamabad shares with Washington (Kabraji, 2012). The ChinaPakistan strategic relationship has strengthened with time under the changing dynamics of regional politics. The strategic bond between China and Pakistan has remained to be on an ascending trajectory stimulated with the push on commercial interaction after the commencement of (CPEC) China-Pak Economic Corridor project since the year 2013 (Hussain and Hussain, 2017).

Gwadar has excessive strategic worth by accumulating Pakistan's prominence in entire areas. It encompasses the significance of Pakistan from the Persian Gulf through the Indian Ocean to Southeast Asia and the Far East. It is located near the Strait of Hormuz, being an energy chokepoint, which is a passageway of 13-millions-barrels of energy supplies per-day (Kalim, 2016). Gwadar is appropriate for the capitalization of trade prospects with energy-rich Afghanistan and the Caspian Sea Region. The strategic communicational networks and trade linkages passing through Gwadar will transform Pakistan into an economic corridor giving enhancement to the interregional economic activities (Azhar, 2015). Gwadar will offer tax concessions and free trade zone opportunities to attract foreign investors to establish economic projects and to bring (FDI) foreign direct investment in Pakistan, based on which it may be able to earn foreign exchange through the transit fee and will increase her foreign exchange reserves (Naseem, 2014). The extent of trade that may be expected to flow through Gwadar suggests that it could produce massive revenues by providing economic and foreign policy choices. Pakistan would become a maritime center by interconnecting the Middle-Eastern energy-producing markets to energy-consuming European \& AngloAmerican market economies with the (CARs) (Javaid and Javaid, 2016).

Gwadar will have the potential for transit trade to generate over $\$ 60$ billion on the annual basis in the future. It has been estimated that $2 / 3$ of the population of Baluchistan will have opportunities regarding port-related activities after its operationalization and with the establishment of transportation interlinks with the Central Asian Republics (CARs), Iran, and China (Hasan, 2012). Gwadar Port project will produce thousands of job opportunities for the people having the potential to handle shipment containers of over 50,000 tons of weight. It will attract foreign investors and may uncover neo panoramas of the development of the regional economy by generating additional revenues \& overcoming security challenges. The seaport has become a requirement of the country in the wake of a growing load of cargo traffic at the existing ports (Azhar, 2015).

Gwadar will bring about extraordinary economic incentives for Pakistan and may place it in the center of the resurgence process for consideration to the leading economies of the region. The 
opening of east-west trading corridors through Gwadar and its expansion to China will break the isolation of Pakistan (Fazl-e-Haider, 2009). The anticipated collection of revenues through strategic energy-supplies transit route and terrestrial to sea-trading from Pakistan would be estimated at $\$ 1,000,000$ per annum (Azhar, 2015). More than 36,000 shipping vessels pass from side to side the area of concern under Pakistan on the annual basis (Hasan, 2012). Pakistan will expectedly generate US\$60 billion a year in transit fees in the next 20 years (Zeb, 2012). The development of Gwadar being an economic hub of the region has resulted in the expansion of strategic infrastructures along with Gwadar to reach out for the energy resources of the (CARs). Chahbahar (Iranian port) and DWP of (UAE port) have been having interests in keeping (Gwadar) out-of race because it would oust them due to its strategic location at an entryway to the Strait of Hormuz. It has been expected that Gwadar will generate about (02)-millions of employment prospects for 8-10 coming years in the future (Azhar, 2015).

Gwadar would be a post of strategic listening for keeping an eye on the regional naval activities of the eastern enemy (Kalim, 2016). It has been going to emerge due to strategic-worth. The emerging security collaboration among India, the US and Israel has been considered detrimental to regional peace and stability, could also undermine the entire balance of security in Asia. Such type of strategic and military assistance may only be counterbalanced with improvement for parallel-strategic and naval-support amid Pakistan and China. Pakistan has less strategic depth from the East to West which would be intensified by Gwadar. Pakistan has been depending upon Bin-Qasim \& Karachi Ports for the sakes of trading and security purposes. On accounts of Indian proximity to India, the seaports have remained vulnerable to disruption (Fazl-e-Haider, 2009). Pakistan had been suffering from a lack of ports for shipment and marine security in the successive conflicts with the Indian Navy that has severely blockaded Karachi by limiting the maneuverability of the Pakistan Navy in the past. Gwadar, being a deep water seaport situated at a distance of $470 \mathrm{Km}$ away from Karachi has seemed to be an ideal outlet to the Indian Ocean from the defense point of view. The deployment of long-range military operatives with long-range capabilities to assault may have to be a substantial risk to the regional maritime geostrategic interests of Pakistan (Kalim, 2016).

Security and its enhancement have been the two facets of the same coin which may reciprocate each other to the extent that one without the other is extremely improbable. Pakistan possesses very trivial geo-strategic profoundness from the "Eastto-West" which may be amplified by Gwadar port being located away from India, to be established due to geostrategic motives of located too far-away for remaining to be prone to marine assault by Indian Navy. Gwadar will also offer natural safeguards against the weather (Hasan, 2012). Gwadar port is situated at a distance of $460 \mathrm{Km}$ further-away from the Indian-boundary rather than Karachi (Azhar, 2015). The long-distance of Gwadar seaport from the adversary positions makes it a safe place to absorb the Indian strikes. Gwadar may substantially lessen the nation's susceptibility to the Indian attack (Hasan, 2012). The rise of India as blue water naval power will have far-reaching implications for Pakistan. The Indian capability to barricade the oil supplies and maritime trade of Pakistan at Karachi shipping port has for a long been remained a security alarm to security-analysts of Pakistan.

Gwadar is an appropriate place for the establishment of the strategic naval 
base as well as for commercial activities. The establishment of the Sensitive Defense Zone (SDZ) at Gwadar seaport will prove to be a correct choice by Pakistan (Javaid and Javaid, 2016). Security experts believe that the deployment of one Agosta 90 B submarine at Gwadar could be able to defend the seaport based on its geographic advantage. Gwadar port may be able to serve as being the third naval base of Pakistan apart from side to side with "Karachi \& Ormara". There had remained threats for naval-blockade by India in past, due to the location of ships at Karachi port (Naseem, 2014).

The geostrategic position of Gwadar port will help to intensify the strategic depth of Pakistan. Pakistan may be capable of averting any assault to naval force, had been observed in the period of past Indo-Pakistani encounters of 1971 and Kargil-crisis of 1999. Militarily seaport (Gwadar) may enhance "strategic-depth" towards the security and marine assets of Pakistan. The Indo-Pak war of 1971 had led towards closing transit trades and energy-supplies by Indian Navy blockade. It will present Pakistan with opportunities for capitalization regarding China-Pakistan companionship despite the fact by attainment of the "strategic-leverage" in connections with Indo-US alliance (Jetly, 2012). Gwadar will empower Pakistan for the adoption of nuclear-assured retaliation defiance termed as a credible minimum deterrence that depends on the availability of a nuclear force at a secure place guaranteeing retaliatory second strike ability against the enemy (Neo, 2013). Pakistan may also adopt the Indian approach of locating marine assets and shipping facilities away from the reach of the enemy. The deployment of NSFcommand at Gwadar may execute the strategic role of serving concerning being a defender of Pakistan's 2nd-strike capability of the nation in retaliation from a safe location. About Pakistan, the second strike capability in retaliation to the enemy attack could be accomplished through the deployment of strategic naval force away from Karachi (Kalim, 2016). Gwadar is situated far from the eastern neighbor of Pakistan and will be able to make available more warning time against air or naval strikes. Gwadar may enable Strategic Forces of Pakistan for the continual observance of the Arabian-Sea area without any interruption regarding retort against hostile-activity by the adversary (Hasan, 2012).

\section{Conclusion}

It is imperative to conclude that Pakistan serves to fulfill several of China's geostrategic objectives in the region. Firstly, the Alliance acts as an effective counterbalance to India's growing influence in the region. Secondly, Pakistan is China's link to the rest of the Muslim world and provides China access to energy-rich countries in the Middle East and Central Asia which is vital for China's mounting energy demand. This in turn could be a key to developing the turbulent region of Xinjiang in China. Thirdly, China seeks to keep a check on the American presence in the region. The China-Pakistan strategic relationship has strengthened with time under the changing dynamics of regional politics. The strategic bond between China and Pakistan has remained to be on an ascending trajectory stimulated with the push on commercial interaction after the commencement of (CPEC) China-Pak Economic Corridor project since the year 2013. The strategic, economic and military potential of Gwadar Port would bring Pakistan and China in dynamic maritime collaboration about the shipment, navigational autonomy, and execution of the international laws of sea and coastline defense. Gwadar will be supportive of China for monitoring (SLOCs) initiating from the Gulf, being a source of about $60 \%$ of the energy requirements of China. It will also make available to China a strategic listening post in IOR for 
detecting any hostile activities by India. It may help for monitoring strategic (SLOCs) emanating from the region of "PersianGulf" and bottleneck at Hormuz-Strait. China has been in the need of a balancer to counterbalance India for dilution of the effects of its hegemonic emergence.

Pakistan is the country that can act as a balancer for China in the region. In this perspective, China has been well aware of the significance of the Pakistan card. Some of the scholars have argued that Gwadar would become a naval base of China in the Indian Ocean enabling Beijing for monitoring Indo-US nautical activities based on which it can also be called the western-most link China under its 'String of Pearls' strategy. Gwadar would be capable of providing a strategic listening outpost to China for observing the US naval activities in the Persian Gulf some $460 \mathrm{Km}$ from Karachi, being further away from Gujrat and Mumbai Naval bases of India. It would prove to be a daunting prophecy as being full-fledged and an offshore naval base of (PLAN) of China. China has been trying to the creation of a knock-back to the US for the magnification of control in the region. It will offer a strategic position to China in the Caspian region rich in energy resources thus giving a substitute trading route for the Chinese province of Xinjiang for utilization as a transit trade route through the deep seaport of Gwadar.

The strategic, economic, and military potential of Gwadar Port would bring Pakistan and China into dynamic maritime collaboration in relation. Gwadar has been dubbed as a crowning jewel in the 'String of Pearls' for China about its geographical advantages of being $400 \mathrm{Km}$ away from the Strait of Hormuz suggesting strategic and military significance. The Indo-US apprehensions have been growing about the involvement of China in Pakistan and have been considered to be a potential threat. It is projected that the US would be relying on
Indian and Japanese naval support to counterweight the influence of China in the designated maritime regions. In case the Strait of Malacca has been blocked by the US, Gwadar Port would be able for serving to be an alternative trade route in the Indian Ocean for China and towards West Asia. In strategic and military expressions, Gwadar Port will be supportive of China for monitoring of (SLOCs) initiating through the Gulf and being a source of about $60 \%$ energy requirements of China. It will also make available to China a strategic listening post, as Beijing would also desire to exercise substantial influence by monitoring the US naval activities in the Gulf and Indian nautical activities in the Arabian Sea, and the future Indo-US naval collaboration.

Gwadar has gained extreme consideration from the very beginning based on its strategic position and the establishment of strong militaristic ties between China and Pakistan. China has been in the need of a balancer to counterbalance India for dilution of the effects of its hegemonic emergence. Pakistan is the country that can act as a balancer for China in the region. In this perspective, China has been well aware of the significance of the Pakistan card. The establishment of a strategic 'naval-base' at the opening of IOR would be helpful to China for observing the hegemonic designs of India in the region. Washington has been viewing Gwadar as being 'Chinese Gibraltar'. The naval presence of China at the significant energy chokepoint of the Gulf would also check the Indo-US dominance of the Indian Ocean. Some of the scholars have argued that Gwadar would become a naval base of China in the Indian Ocean enabling Beijing for monitoring Indo-US nautical activities based on which it can also be called the western-most link China under its 'String of Pearls' strategy. From the military and strategic perspectives, Gwadar would help 
China for monitoring (SLOCs) emanating from the Persian Gulf. The naval presence of China may likely strengthen the coastline defense of Pakistan. With the stationing of Chinese marines at such a vital position, China would be in the position of monitoring activities by the US naval forces as well as it will also have the capability of striving for achieving the status of being a world naval power. Gwadar Port will facilitate China with strategic footholds in IOR, which would prove to be a daunting prophecy as being full-fledged and an offshore naval base of (PLAN) of China. In the geostrategic and military perceptions, Gwadar would be a post of strategic listening for keeping an eye on the regional naval activities of the eastern enemy.

Pakistan had been suffering from a lack of seaports for shipment and marine security in the successive conflicts with the Indian Navy that has severely blockaded Karachi by limiting the maneuverability of the Pakistan Navy in the past. Gwadar, being a deep water seaport situated at a distance of $470 \mathrm{Km}$ away from Karachi has seemed to be an ideal outlet to the Indian Ocean from the defense point of view. The long-distance of Gwadar from the adversary positions makes it a safe place to absorb the Indian strikes. Gwadar is an appropriate place for the establishment of the strategic naval base as Security experts believe that the deployment of one Agosta 90 B submarine at Gwadar could be able to defend the seaport based on its geographic advantage. The geostrategic position of Gwadar will help to intensify the strategic depth of Pakistan. It will empower Pakistan for the adoption of nuclear-assured retaliation defiance termed as a credible minimum deterrence that depends on the availability of a nuclear force at a secure place guaranteeing retaliatory second strike ability against the enemy. The deployment of NSF-command at Gwadar may execute the main part of serving as well as for also being a defender of Pakistan's the 2ndstrike potentiality of Pakistan in retaliation from a safe location. Gwadar is situated far from the eastern neighbor of Pakistan and will be able to make available more warning time against air or naval strikes. Gwadar would empower Pakistan's Naval Forces to observe the span of IOR without any interruption for appropriate retaliation to any antagonistic action by an adversary. Based on the above discussion, it can be concluded that the China-Pakistan strategic relationship has been established to be a win-win situation for both China and Pakistan. The china-Pak strategic coalition has been defined by officials as being an equally advantageous relationship built on respect and "multi-dimensional" collaboration. China and Pakistan jointly will outline the security architecture of Asia and may determine regional economic and strategic terrain for many years to come.

\section{References}

[1] Azhar, Ahmad. 2009. "Maritime Security Post-9/11: Challenges and Response." Journal of the Institute of Strategic Studies of Islamabad XXIX (2\&3), 86-100.

[2] 2015. "Gwadar: Potential and Prospects." Pak Institute for Conflict and Security Studies (PICS), (January 29). http://www.picss.net. (accessed October 23, 2019).

[3] Darshana, Baruah. 2018. "India's Answer to the Belt and Road: A Road Map for South Asia." Carnegie Endowment for International Peace, (August). http://www. carnegieIndia.org. (accessed July 15, 2020).

[4] Fazl-e-Haider, Syed. 2009. “Gwadar: An Emerging Centre of the New Great Game." ISPI Policy Brief 16. http://www.ispion line.it, (October 
10). http://www.ispion line.it. (accessed December 19, 2019).

[5] Gill, Don Mclain. 2019. "The Geopolitics of the China-Pakistan Economic Corridor(CPEC) and its Security Implications for India." The Korean Journal of International Studies Vol. 17, No. 3 (December 2019), 337-354.

[6] Hasan, Malik . 2012. "Strategic Importance of Gwadar Port." Journal of Political Studies 19(2), 57-69.

[7] Hussain, Fakhar. 2020. "Geostrategic Imperatives of Gwadar Port for China." The Korean Journal of International Studies Vol.18, No.2 (August 2020), 145-167.

[8] Hussain, Fakhar and Hussain, Mezhar 2017. "China-Pak Economic Corridor (CPEC) and its Geopolitical Paradigms." International Journal of Social Science, Humanities and Education 1(2), 79-95.

[9] Javaid, Umbreen and Javaid, Rameesha. 2016. "Stregthening Geostrategic Bond of Pakistan and China Through Geo-Economic Configuration." Pakistan Economic and Social Review, 54.

[10] Jetly, Rajshree. 2012. "Sino-Pakistan Strategic Entente: Implications for Regional Security.” http://www.isas.nus.edu.sg, (Feburary 14). http://www.isas.nus.edu.sg. (accessed July 10, 2020)

[11] Kabraji , Rosheen. 2012. "The China-Pakistan Alliance: Rhetoric and Limitations." Chatham House , (December).

http://www.chathamhouse.org. (accessed May 23, 2020).

[12] Kakar, Tariq. 2014. "Strategic Importance of Gwadar Port." http://thebalochistanpoint.com/strate gic-importance-of-gwadar-port, (June 15). http://thebalochistanpoint.com/strate gic-importance-of-gwadar-port (accessed July 18, 2019).

[13] Kalim, Inayat. 2016. "Gwadar Port: Serving Strategic Intrests of Pakistan." A Research Journal of South asian Studies 31(1), 207-221.

[14] Naseem, Naheeda. 2014. "Geopolitical Value of Gwadar for the Region (Mainly for Pakistan, China and the Region)." South Asian Studies, Vol. 29, No. 2, JulyDecember, 519-530.

[15] Neo, Christabel. 2013. "China's Gwadar Pearl: The Port acquisition and implications for India." Institute of South Asian Studies Brief, No. 288. http://www.isas.nus.edu.sg. (accessed November 27, 2019).

[16] Pascu, Mihai. 2011. "The GeoStrategic Importance of the Indian Ocean in the Context of the World Oil Crisis." Bulletin of the Transilvania University of Brasov 4(53), No. 1, Series V, 221-226.

[17] Schwemlein, James. 2019. "Strategic Implications of the China- Pakistan Economic Corridor". United States Institute of Peace, (December 16). http://www.usip/publications/2019/1 2/strategic-implications-chin. (accessed April 27, 2020).

[18] Shahnaz, Iqra. 2015. "Gwadar Port: Challenges and Opportunities." http://www.incpak.com/editorial/gwa dar-port-challenges-opportunities,

(Feburary

17). http://www.incpak.com/editorial/gwa dar-port-challenges-opportunities. (accessed May 23, 2019).

[19] Small, Andrew. 2015. The ChinaPakistan Axis: Asia's New Geopolitics. London: Hurst \& Co.

[20] Yan, Wong. 2012. "Securing the New Silk Route." http:/ /www.newchinamag.com/magzine/se curing-the-new-silk-route/, (Feburary 17). A http:/ /www.newchinamag.com/magzine/se 
curing-the-new-silk-route/. (accessed November 23, 2019).

[21] Yeuh-Yun, Leo. 1972. China as a Nuclear Power in World Politics. London: Palgrave Macmillan.

[22] Zeb, Rizwan. 2012. Pakistan-China Relations: Where They Go From Here? UNISCI Discussion Papers, No. 29, pp. 45-58. 